日臨外会誌 $63(11), 2724-2729,2002$

症例

病変内に膿瘍を形成した横行結腸 inflammatory fibroid polyp の 1 例

\author{
市立宇和島病院外科 \\ 岩川和秀田中仁梶原伸介 \\ 小野芳人 蜂須賀康已岡田憲三
}

症例は59歳, 女性. 発熱精查中, 注腸および大腸内視鏡検査にて横行結腸に $3 \mathrm{~cm}$ 大の 有茎性隆起病変を認め，ほかに発熱の原因と思われる異常を指摘できないため, 横行結 腸切除術を施行した，術後発熱および炎症所見は速やかに消退した. 切除標本にてポり ープ椂病変の頭部内に $1 \mathrm{~cm}$ 大の膿崵を認めた。組織学的には, 粘膜下層を中心に炎症性 細胞浸潤と細血管周囲の線維性結合織の同心円状配列を認め inflammatory fibroid polyp (IFP) と診断された. IFPにおいて急性炎症が関与している可能性が示唆され， 自験例はIFPの病因や病態を考える上で貴重な症例と思われる。

索引用語 : inflammatory fibroid polyp (IFP), 膿瘍, 大腸ポリープ

はじめに

Inflammatory fibroid polyp（以下 IFP）は食道か ら大腸までの全消化管に発生し, 種々の炎症性細胞浸 潤と線維性結合織の増生を主体とするポリープ状病変 で，その成因は一種の炎症性変化と考えられているが 詳細は不明である。今回われわれは，発熱を主訴に発 症し, 病変内に膿瘍を形成した横行結腸 IFP の 1 例を 経験したので文献的考察を加えて報告する.

\section{症例}

患者：59歳，女性.

主訴：発熱。

既往歴, 家族歴：特記すべきことなし。本人および 家族にアレルギー性疾患の既往なし.

現病歴: 平成13年 3 月初頃より 38 度前後の発熱を認 め, 近医にて感冒として治療を続けていたが改善しな いため 3 月26日本院内科外来を受診した，血液検查に て炎症所見を認めたため, 同日入院し原因検索を行っ たところ, 横行結腸に隆起性病变を認めた。 その後も 発熱が持続し，ときどき下血を認めるようになったた め手術目的に 5 月 10 日外科転科となった。

入院時現症: 身長 $154 \mathrm{~cm}$, 体重 $52.5 \mathrm{~kg}$, 血圧 $130 / 70$, 体温 $38.2^{\circ} \mathrm{C}$, 眼瞼結膜に唃血を認めず, 眼球結膜に黄

2002 年 6 月 10 日受付 2002 年 8 月 8 日採用

〈所属施設住所〉

テ798-8510 宇和島市御殿町 $1-1$
㾝を認めず．腹部は平坦で，上腹部に軽い圧痛を認め た.

入院時検査所見：末梢血では，白血球数 13,100 / $\mathrm{mm}^{3}$ と増加し，好中球 $76 \%$ と増加を認めたが，好酸球 は $3 \%$ と正常範囲内であった. また血沈 $138 / \mathrm{hr}$ と亢進 L, CRP $13.05 \mathrm{mg} / \mathrm{dl}, \quad \gamma$-グロブリン $2.31 \mathrm{~g} / \mathrm{dl}$ と高值 を示し，持続する全身性炎症性所見を認めた。肝機能, 電解質, 尿, 冀便検査にて異常を認めなかった。腫湟 マーカー（CEA）の上昇も認めなかった.

注腸造影所見：横行結腸のほほ中央に頭部が $33 \times 20$ $\mathrm{mm}$ で茎が $12 \mathrm{~mm}$ の有茎性隆起病変を認めた。病変部

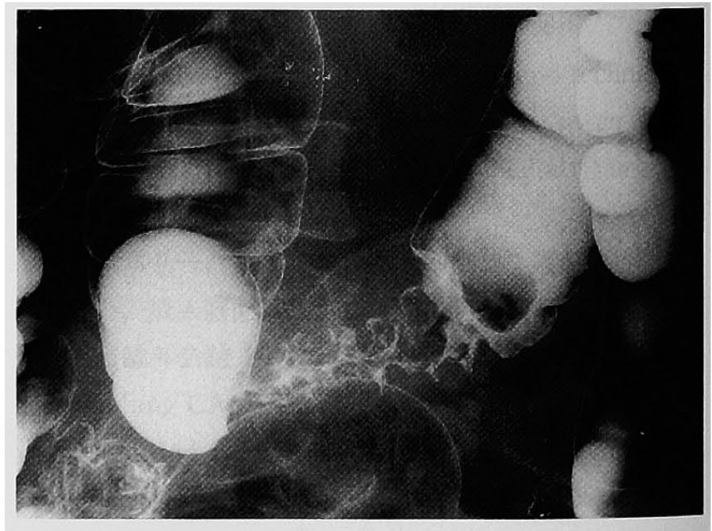

図 1 注腸造影検查: 横行結腸のほ 病変を認め, 病变部口側腸管に両側性に伸展不良を認め た。 


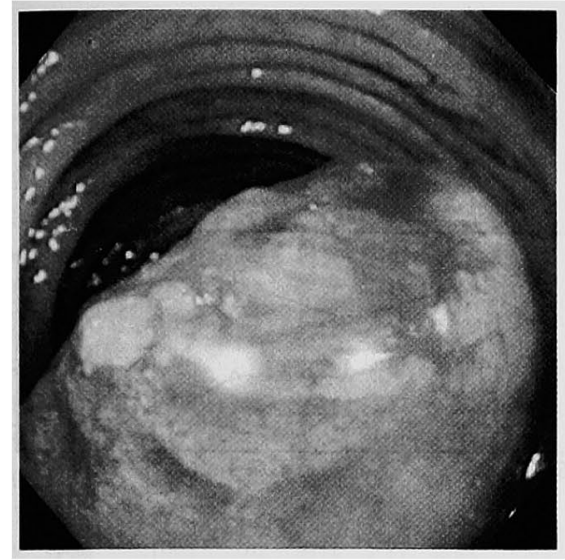

图 2 大腸内視鏡検査：横行結腸に約 $3 \mathrm{~cm}$ 大の有荃性隆起病変を認奻。. 頭部は光沢 を有し，頂部は発赤，びらんあり一部結節 状を呈していた。

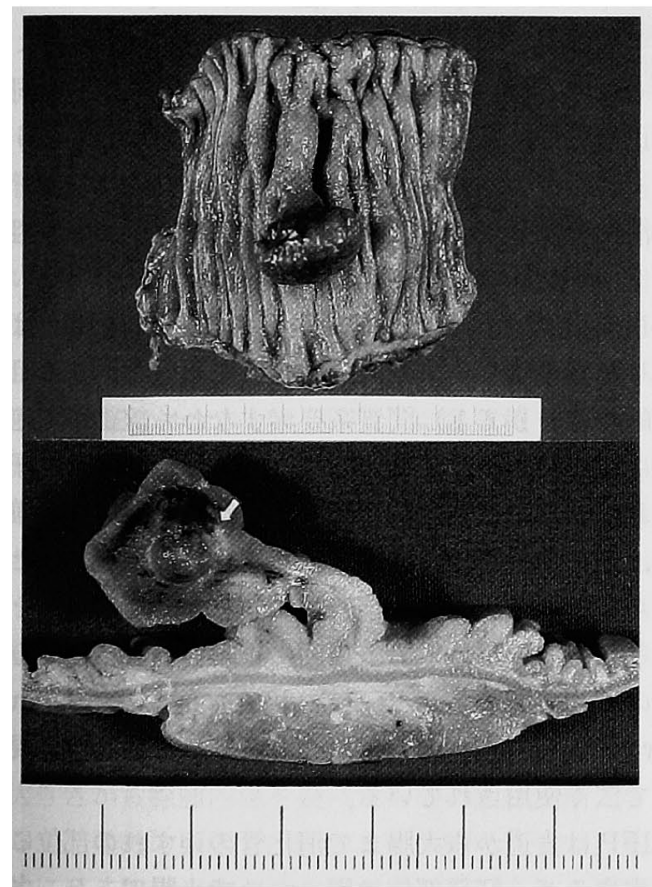

図 $3 \mathrm{a}$ 切除標本：茎の太さは $0.8 \mathrm{~cm}$ の有茎性腫 瘤で, 病変の茎部は粘膜で覆われていたが, 頭部 は粘膜が欠損し発赤とびらんを認めた。

b 切除標本滑面：腫瘤の頭部内に $1 \mathrm{~cm}$ 大の 朖瘍形成を認めた (矢印). 病変部付近の腸管壁特 に獎膜面は脂肪織の肥厚を認めた。

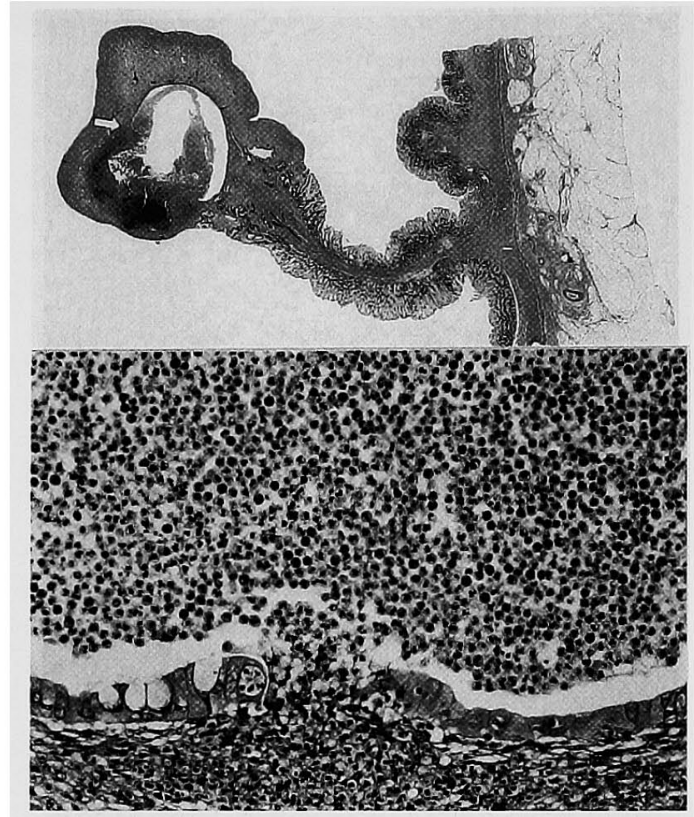

図 4 病理組織学的所見 1 (H. E.)

a 弱拡大 (ルーペ像)：頭部から頸部にかけて粘 膜上皮は脱落しており，頭部内には呩瘍形成を認め た（矩印).

b 膿瘍部強拡大：膿瘍は好中球を多く含んでお り, 膿瘍周囲は 1 層の腺上皮で覆われ,一部間質へ穿 破していた (×200).

$$
\frac{a}{b}
$$

口側腸管は約 $10 \mathrm{~cm}$ にわたって両側性に伸展不良を認 めた（図 1 ).

大腸内視鏡所見：横行結腸に約 $3 \mathrm{~cm}$ の有茎性隆起 病変を認めた．頭部は光沢を有し，頂部は発赤，びら んあり一部結節状を呈していた（図 2 )。頭部からの生 検では易出血性のため十分な組織が得られず，茎部か らの生検では過形成腺管（Group 1）のみであった.

以上の画像所見からだけでは隆起病変の質的診断は 困難であり，ときどき下血も認め，ほかに発熱の原因 となる異常を認めなかったため，5月14日開腹手術を 施行した。

手術所見：横行結腸ほほ中央の腸間膜付着側に約 3 $\mathrm{cm}$ の腫瘤を触知し, 可動性は良好であった. 病変部付 近の槳膜面の脂肪織は肥厚し，連続して結腸間膜のび まん性肥厚および所属リンパ節の腫大を認め, 病変部 周囲への炎症の波及が示唆された。炎症部分を含め病 変より口側, 肛門側それぞれ約 $10 \mathrm{~cm}$ 離して横行結腸 を部分切除し（D1）端々吻合した。 


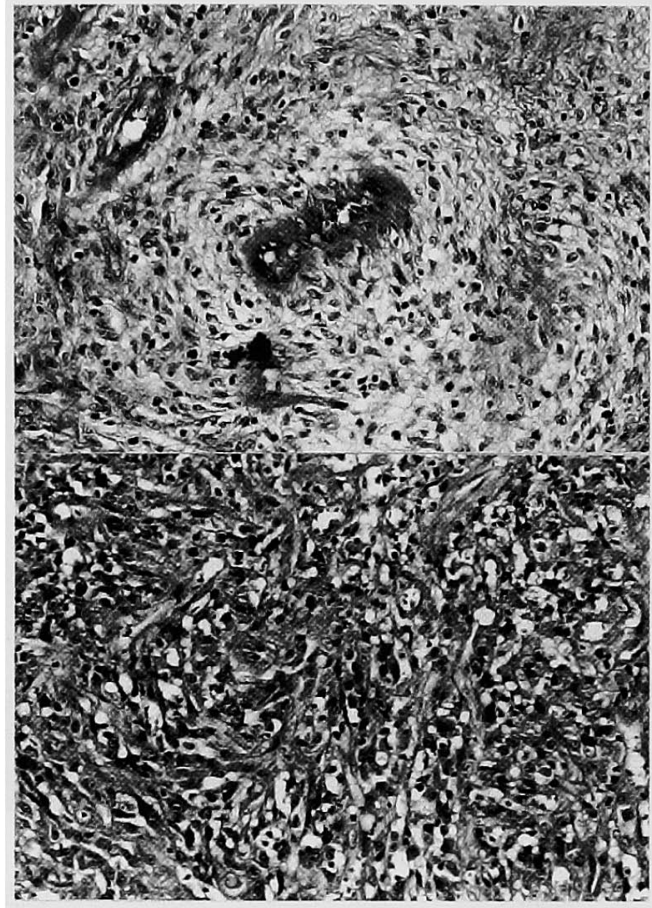

図 5 病理組織学的所見 2 (H. E.) : a) 粘膜下層を 中心にリンパ球, 好酸球を含む好中球, 線維芽細胞 等の炎症性細胞浸潤がみられ，細血管周囲には増 生した線維性結合織が同心円状及び索状配列を示 した $(\times 200)$. b ) 頭部表層付近には紡錘形細胞の 偽肉腫樣增殖を認めた $(\times 200)$ 。

摘出標本の肉眼所見：腸間膜側に頭部は2.8×2.0 $\mathrm{cm}$ で, 茎の太さは $0.7 \mathrm{~cm}$ で長さが $1.0 \mathrm{~cm}$ の有茎性ポ リープを認めた.病変の茎部は粘膜で覆われていたが, 頭部は粘膜が欠損し発赤とびらんを認めた。また割面 にて病変の頭部内に約 $1 \mathrm{~cm}$ の膿瘍形成を認めた。病 变部付近の腸管壁特に槳膜面は脂肪織の肥厚を認めた

(図 3 a , b).

病理組織学的所見：頭部から頸部にかけて粘膜上皮 は脱落しておう，頭部内には好中球を中心とした膿瘍 形成を認めた。膿摥周囲は 1 層の腺上皮で覆われてお り，一部間質へ穿破していた（図 $4 \mathbf{a} ， \mathrm{~b}$ ). 粘膜下層 を中心にリンパ球，好酸球を含む好中球，線維芽細胞 等の炎症性細胞浸潤がみられ，細血管周囲には増生し た線維性結合織が同心円状㧍よび索状配列を呈してい た．頭部表層付近には紡龲形細胞の異常增殖を認め, S-100 蛋白とサイトケラチン染色でいずれも陰性であ ることより偽肉腫様変化と診断した．頸部付近の腺管

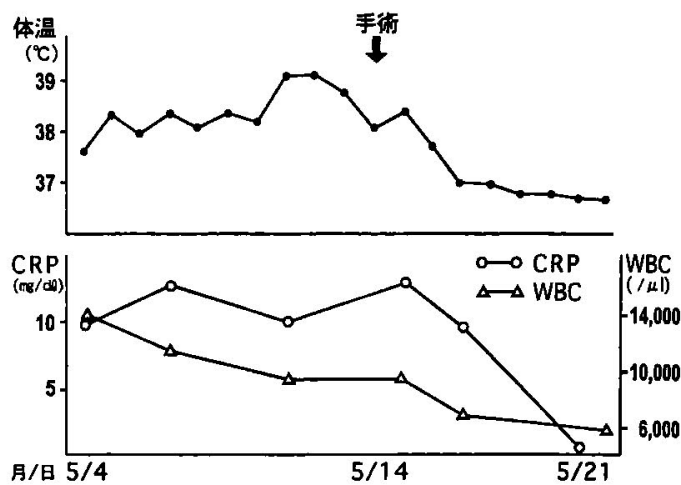

図 6 臨床経過

は大小不同を認めた，病変部付近の漿膜面には脂肪織 炎を認めた．郭清されたリンパ節は反応性のリンパ濾 胞の腫大であった．以上の病理所見より急性の炎症所 見を伴う IFP と診断した（図 5 a， b)。

手術後発熱はすみやかに消失し, 術後 3 日目より $37^{\circ} \mathrm{C}$ 以下となった．また白血球数，血沈， CRP も同時 に正常化し, 以後再発の兆候は認めていない（図6).

\section{考 察}

消化管に発生する原因不明の好酸球浸潤を伴う肉芽 腫性病変に対して，1920年 Konjetzny ${ }^{1}$ が胃の polypoid fibromaとして報告して以来, Vanek ${ }^{2)}$ 蝢 似した胃のポリープ様肉芽腫 6 例を報告し，その組織 学的特徵として 1 ）間質系要素すなわち線維芽細胞と 粗に配列した膠原線維の増生，2）好酸球を含む好中 球抢よびリンパ球浸潤と時に見られるリンパ滤胞様構 造，3）細小動脈，静脈，リンパ管の存在をあげた。 さらに1953年 Helwig ら゙は線維性結合織の増生を主 体とし，血管が豊富で，周囲に線維性結合織の同心円 状の配列を認めるポりープ様病変に対し，inflanmatory fibroid polyp (IFP) と命名し，この名称が現在 まで広く使用されている。

IFP は食道から大腸まで消化管のいずれの部位にも 発生するが，好発部位は胃，ついで小腸であり，大腸 は比較的稀とされている4.．本邦では1975年西原ら ${ }^{5}$ が 最初に報告して以来, 自験例を含めて20例であった(表 1)。本邦竍告例を検討すると，年齢は 1 墄より 71歳ま でで平均45.5歳であり, 性別は男性 7 例, 女性13例で 女性にやや多かった，ポリープは全例単発で，発生部 位は虫垂 2 例, 盲腸 6 例, 上行結腸 1 例, 横行結腸 7 例, 下行結腸 1 例, S 状結腸 3 例とやや右側結腸に多く 認められた，主訴は腹痛 8 例，便潜血陽性を含めた消 
表 1 大腸 IFP 本邦報告例

\begin{tabular}{|c|c|c|c|c|c|c|c|c|c|c|c|}
\hline \multicolumn{2}{|c|}{ 報告者 } & 報告年 & 年龄 & 性別 & 部位 & 主訴 & 肉眼型 & 大きさ $(\mathrm{cm})$ & 術前診断 & アレルギー歴 & 治撩 \\
\hline 1 & 西原 & 1978 & 41 & 女性 & 盲腸 & 下血 & 無菱 & $6 \times 3.5 \times 3.5$ & 回盲部腫瘤 & なし & 腹切除 \\
\hline 2 & 松崎 & 1979 & 69 & 女性 & 横行 & 椱痛 & 有菱 & 2.5 & 結晹瘾 & なし & 腸切除 \\
\hline 3 & 杉村 & 1981 & 1 & 女性 & 下行 & 肛門脱出 & 無茎 & $3.5 \times 2.7 \times 1.2$ & 平滑筋肉嗹 & なし & 腸切除 \\
\hline 4 & 鉿木 & 1983 & 20 & 男性 & 横行 & 心窝部不快 & 有茎 & $4.5 \times 3.5 \times 2.5$ & 結腸腄湯 & なし & 腸切除 \\
\hline 5 & 清水 & 1984 & 32 & 男性 & 盲腸 & 下腹部痛 & 有茎 & $3.5 \times 2.5 \times 2.5$ & 結腸摈 & なし & 腸切除 \\
\hline 6 & 福田 & 1985 & 48 & 男性 & 盲腸 & 下血 & 有茎 & 3.0 & ポリーフ & 記截なし & 腸切除 \\
\hline 7 & 宮川 & 1990 & 7 & 女性 & 横行 & 触血 & 有茎 & $5.2 \times 4.7 \times 3.4$ & 結腸尰湶 & 記載なし & 腸切除 \\
\hline 8 & 山際 & 1990 & 41 & 男性 & 虫垂 & 腹痛 & 腄溜状 & $3 \times 3$ & 虫垂腫瘤 & なし & 虫垂切除 \\
\hline 9 & 田口 & 1992 & 32 & 女性 & S状 & 左下腹部痛 & 有茎 & $4.0 \times 3.6 \times 3.4$ & 粘膜下腫場 & 記臷なし & 腸切除 \\
\hline 10 & 今津 & 1993 & 43 & 男性 & S状 & 榆診 & ソーセージ様 & $3.0 \times 2.0$ & ポリープ & なし & 腸切除 \\
\hline 11 & 友近 & 1993 & 71 & 女性 & 横行 & 便潜血 & 無茎 & $2.0 \times 1.5$ & ポリープ & なし & 内視鏡摘除 \\
\hline 12 & 平崎 & 1994 & 70 & 男性 & 上行 & 発熱 & 有茎 & $0.4 \times 0.6 \times 0.5$ & ポリープ & 記載なし & 内視金篭摘除 \\
\hline 13 & 板倉 & 1994 & 62 & 女性 & 横行 & 左下腹部痛 & 無茎 & 0.5 & ポリープ & 記載なし & 内視鏡摘除 \\
\hline 14 & 岩绮 & 1994 & 66 & 女性 & 盲腸 & 右下腹部痛 & ソーセージ様 & $2.0 \times 2.0 \times 5.0$ & 結腸癌 & 記载なし & 腸切除 \\
\hline 15 & 营 & 1997 & 45 & 女性 & 盲腸 & 便潜血 & 有茎 & $14.3 \times 2.2 \times 2.0$ & ボリープ & 記载なし & 内視鏡摘除 \\
\hline 16 & 伊藤 & 1998 & 40 & 女性 & S状 & 便潜血 & 有茎 & $1.2 \times 0.8 \times 0.7$ & ボリープ & 記裁なし & 内視鏡摘除 \\
\hline 17 & 浜本 & 1999 & 41 & 男性 & 虫垂 & 便潜血 & 無茎 & $1.2 \times 1.2$ & 粘膜下腫瘤 & 記韯なし & 腸切除 \\
\hline 18 & 一宮 & 1999 & 69 & 女性 & 横行 & 便潜血 & 有茎 & $3.5 \times 7.0$ & 結腸癌 & 記载なし & 腸切除 \\
\hline 19 & 田中 & 1999 & 46 & 女性 & 盲腸 & 筫血 & 有茎 & $3.7 \times 3.3 \times 2.3$ & ボリープ & あり & 内視鏡摘除 \\
\hline 20 & 自験例 & 2002 & 59 & 女性 & 横行 & 発熱 & 有茎 & $3.0 \times 2.8 \times 3.7$ & ポリープ & なし & 腸切除 \\
\hline
\end{tabular}

化管出血が 5 例と多く，発熱を主訴とした症例は自験 例以外に松崎らの報告例 ${ }^{6}$ とサルモネラ腸炎を併発し ていた平崎ら゙の報告例のみであった。肉眼型は，14例 が有茎性で 6 例が無茎性であり，大きさは最大径の平 均が $3 \mathrm{~cm}$ であり,大型のものは少なかった。また腸 のIFPほどではないが 4 例(18) -10)に腸重積を合併して いた.

IFP は隆起が主体であり，術前の存在診断は容易で あるが，質的診断や悪性疾患との鑑別は困難なことが 多く，術前診断できていた症例は皆無であった。術前 に結腸癌と診断された症例が 4 例で，粘膜下腫瘍が 2 例，非上皮性悪性腫瘍が 1 例であり，その他の多くは 結腸腫瘍か結腸ポリープの術前診断であった，自験例 も大きさから腺腫内癌を疑ったものの組織診断できて おらず，発熱の原因も不明のまま手術となった。内視 鏡的には，腫瘤が大きくなってくるとびらんや潰惶を 形成しやすくなり，粘膜下腫瘤状の隆起上皮が久損す ると陰茎重頭椂外観を呈するとの報告が多くみられれ11 本疾患の特徵とされている. 自験例もポリープ先端の 上皮が欠損することにより通常の腺腫性ポリープと異 なった光沢を呈しており，生検で腫崵を認めなかった ことからも鑑別診断上本症を考慮する必要があったも のと思われる。

治療については良性疾患であることから over sur - gery は慎むべきであるが, 出血や通過障害を認めた り，癌性ポリープとの鑑別が難しいことより20例中14 例は開腹下に腸管切除されている。しかし病変基部が $1 \mathrm{~cm}$ 位までの有茎性病変で, 悪性の可能性が低いと 診断できれば，内視鏡的摘出術を行うことも診断およ び治療に有用であり，最近では内視鏡的に摘除した報 告例も增加しつつある．自験例でも有茎性の病変であ ることより内視鏡的摘出も考慮すべきであったと考え られるが，ポリープのみが発熱の原因としては考えが たく，注腸等の所見より腸間膜脂肪織炎などの腸管外 病変の検索を併せて行う目的で開腹による腸管切除を 行った。

本疾患の発生機序として Kaijser ${ }^{121}$ は食物成分に対 するアレルギー説を唱えたが，その後もアレルギー因 子の関与を認めがたい症例が多く，本邦報告例でも記 載のあった症例のうちアレルギーを有する症例は 1 例 のみであった。また組織学的類似性より腫湟説も提唱 されたが，宮川ら は増殖の主体を占める紡銛形の細 胞を免疫組織学的および電顕的に検討し，神経や血管 由来ではなく myofibroblast の混在した fibroblast で あり，肉芽組織に類似した間葉細胞の異常増殖と説明 している. 本例でも紡錘形細胞の S-100 蛋白とサイト ケラチン染色では陰性であり，神経由来や肉腫の可能 性は否定的であった。組織学的には炎症性細胞浸潤, 
毛細血管の增生を伴う結合織の増生が主体であること から現在では炎症説が有力であり，消化管局所の組織 椇傷に対してなんらかの刺激が加わり，組織の過剩反 応としてIFPが形成されるものと考えられている4． 自験例では, 組織学的にポリープ先端付近で偽肉腫様 変化を認めたり，頸部付近で腺管の大小不同を認めた ことより, 同部でくり返し上皮の損傷, 脱落, 再生が あり，粘膜 barrier が破壊され細菌が侵入しやすい状 態にあったことが考えられる。しかしIFP内に化膿性 膿瘍を形成した病態については 1）IFPに偶然急性膿 瘍が合併した，2）本来 IFPはある自相において急性 炎症を伴っている，3）急性膿瘍が何らかの誘因とな りIFPが形成された，等が考えられるが，あくまでも 想像の域を出ない。いずれにしろこの滕湯形成が全身 の発熱, 炎症所見, 局所の腸管漿膜面や脂肪織の変化 等を反映し,病変部切除により改善したものと思われ， 今後も症例の蓄積と病態についてのさらなる検討が必 要と考える.

\section{結＼cjkstart語}

熱発を主訴とし，病変切除後にすみやかに解熱した 横行結腸の IFP を経験した. IFP 病変内に化膿性膿場 を形成した症例としては初めてであり，IFP の原因や 病態を考える上で貴重な症例と考えられる。

謝 辞

稿を終えるにあたり，病理組織学的検討についてご助言 を頂きました当院病理科の栗原憲二先生に媣謝いたしま す.

本論文の要旨は第16回要媛炎症性腸疾患研究会, 第278回 宇和島胃腸疾患研究会において発表した。

\section{文献}

1) Konjetzny GE: Uber Magenfibrome. Beitr Klin Chir 119:53-51, 1920

2) Vanek J: Gastric submucosal granuloma with eosinophilic infiltration. Am J Pathol 25:397 $-411,1949$

3) Helwig EB, Ranier A: Inflammatory fibroid polyp of the stomach. Surg Gynecol Obstet 96 : 355-367, 1953

4) Johnstone JM, Morson BC: Inflammatory fibroid polyp of the gastrointestinal tract. Histopathology $2: 349-361,1978$

5）西原幸一, 水島睦枝, 伊藤慈秀他：盲腸の Inflammatory fibroid polyp の 1 例。癌の臨 $24: 1311$ $-1316,1978$

6）松崎松平, 菊池一博, 岩村健一郎他：大腸に発生 した Eosinophilic Granuloma (Inflammatory Fibroid Polyp）の 1 例. 日消病会誌 $76: 126-$ 132,1979

7）平崎照士，洲脇㯵一郎，岡咲博昭他：内視鏡的ポ リペクトミーにより切除し得た大腸 Inflamma. tory Fibroid Polyp $の 1$ 例. Gastroenterol Endosc $36: 782-787,1994$

8）杉村公平, 橋本 俊, 加藤文彦他：大腸の Inflam matory fibroid polyp $の 1$ 例. 日本大腸肛門病会 誌 $34: 26-30,1981$

9）田口久雄, 高原聡, 楠本征夫他：S 状結腸 Inflammatory Fibroid Polypの 1 例. Gastroenterol Endosc 35:335-341, 1993

10）岩崎 茂, 水口滋之, 大和田進地：盲腸の inflam matory fibroid polypによる成人腸重積症の 1 例。日臨外会誌 $55: 2616-2620,1994$

11）浦岡正義，判上忠彦，岩下明徳他：巨大な胃 Inflammatory fibroid polypの1例。胃と腸 $23: 95-101,1988$

12) Kaijser $R:$ Zur Kenntnis der allergishen Affektionen des Verdauungskanals vom Standpunkt des Chirurgen aus. Arch Klin Chir 188, 3664, 1937

13）宮川智幸, 西村 洋, 小泉 勉他：大腸 Inflammatory Fibroid Polyp の免疫組織化学的および電影 的検討. 埼玉小児医療センター医誌 $70: 721$ 731,1990 


\title{
A CASE OF AN INFLAMMATORY FIBROID POLYP OF THE TRANSVERSE COLON WITH PYOGENIC ABSCESS IN THE LESION
}

\author{
Kazuhide IWAKAWA, Hitoshi TANAKA, Shinsuke KAJIWARA, \\ Yoshihito ONO, Yasuki HACHISUKA and Kenzo OKADA \\ Department of Surgery. Uwajima Municipal Hospital
}

\begin{abstract}
A 59-year-old woman was admitted to the hospital because of fever. During close inspection for fever, a barium enema study and a colonoscopy showed a pedunculate elevated lesion with the diameter of $3 \mathrm{~cm}$ in the transverse colon. Besides the lesion, no abnormalities probably causing fever were detected, and a transverse colectomy was performed. Fever and inflammatory findings disappeared immediately after the operation. On the resected material, an about $1 \mathrm{~cm}$ pyogenic abscess was present in the head of the polyp like lesion. Histological diagnosis was inflammatory fibroid polyp (IFP), because infiltration of inflammatory cells mainly in the submucosa and concentric arrangement of fibrous connevtive tissue in the vicinity of microarteries were observed.

It is suggested that acute inflammation might participate in IFP, and this case is thought to be valuable in the consideration of causes and pathogenesis of IFP.
\end{abstract}

